\title{
Fernando SAVATER, Acerca de Santayana
}

ed. by José Beltrán \& Daniel Moreno, Valencia, PUV, 2012

\section{Ángel M. Faerna}

\section{(2) OpenEdition \\ 1 Journals}

Electronic version

URL: http://journals.openedition.org/ejpap/750

DOI: 10.4000/ejpap.750

ISSN: 2036-4091

\section{Publisher}

Associazione Pragma

\section{Electronic reference}

Ángel M. Faerna, «Fernando savater, Acerca de Santayana », European Journal of Pragmatism and American Philosophy [Online], IV-2 | 2012, Online since 24 December 2012, connection on 24 September 2020. URL : http://journals.openedition.org/ejpap/750 ; DOI : https://doi.org/10.4000/ ejpap.750

This text was automatically generated on 24 September 2020.

\section{(1) () $(9$}

Author retains copyright and grants the European Journal of Pragmatism and American Philosophy right of first publication with the work simultaneously licensed under a Creative Commons AttributionNonCommercial-NoDerivatives 4.0 International License. 


\title{
Fernando SAVATER, Acerca de Santayana
}

ed. by José Beltrán \& Daniel Moreno, Valencia, PUV, 2012

\author{
Ángel M. Faerna
}

\section{REFERENCES}

Fernando SAVATER, Acerca de Santayana, ed. by José Beltrán \& Daniel Moreno, Valencia, PUV, 2012

1 This book compiles 17 short pieces in which the renowned Spanish philosopher and intellectual Fernando Savater (San Sebastián, 1947) evokes the thought and character of George Santayana. The selection spans over more than 30 years - the earliest text was originally published in 1977 and the last one dates from 2010 -, revealing Savater's sustained interest in, and fondness for the figure of Santayana. Completing the collection of self-contained texts there are two more sections: one of fragments picked up from other writings by Savater in which the author makes a significant use of quotations from Santayana in order to illustrate or reinforce his own ideas, and the third one consisting of extracts from published interviews and conversations where Savater occasionally praises the opinions of the Spanish-American philosopher and pays tribute to his teaching.

In a brief Introduction, the editors account for their purpose in compiling a volume that they do not hesitate to brand as "atypical" (17). Profs. Beltrán and Moreno are not only competent scholars but also enthusiastic promoters of whatever initiatives that can make Santayana's philosophy better known among the Spanish public. Thus, it is only natural that they intended to make the most of the fact that one of the more conspicuous intellectuals in the present Spanish (and Hispanic) milieu has paid such an enduring attention to their philosophical hero. To this extent the move is both astute and effective. But they point at the second reason that made the project appealing to them: to explore the elective affinity that Savater overtly feels toward the thinker 
whose vision and temperament were diametrically opposed to his in many respects. Trying to solve this riddle is probably the more stimulating challenge of the book, because the Introduction does not go into it in any depth. The editors pose the question "How to explain Savater's interest in Santayana?" (18) but then let the reader find the answer as she reads the book.

Let me begin with some obvious contrasts. Fernando Savater has the typical profile of a public intellectual, someone who is eager to engage in social and political debates and to influence public opinion. Indeed he is a skilled polemist - he likes to describe his writings as 'diatribes' - and has a regular presence in the mass media. This disposition is clearly at odds with the characteristic detachment of Santayana, who always looked distantly at the conflicts and agitations of his time. Secondly, and more substantially, Savater's philosophical stance is ethically oriented; he is what Richard Rorty used to call an 'edifying philosophe,' or even an educator. The philosophy of Santayana, on the contrary, though it certainly can inspire definite ethical views, is nevertheless grounded on a deliberately de-humanized perspective on things: in Santayana it is not only possible but almost inevitable that the several threads of his thought culminate in a sort of metaphysical vision, a dimension which is absolutely lacking in Savater's case. Finally, there are important differences in the way each philosopher envisages their own tasks. Savater does not feel at ease with being described as a 'philosopher,' he finds the name too ambitious and too pretentious for him. As he cleverly puts it in one of the conversations included in the book: "the great masters [like Santayana] avoided engagement because they were persuaded that the others would look for them and that they would be eventually heard. I do not assume to be worthy of being looked for, it is me who goes to meet others, like those who stand on the side of the road spraying cold water over the passing cycle-race, refreshing some of the cyclists and maybe disturbing others" (186). Santayana, in turn, looks exactly like the kind of philosopher who displays his thinking irrespective of what the world would say or expect, just waiting for a sympathetic reader to appear.

On the other hand, there are also similarities that make Savater's interest in Santayana less improbable. For one thing, they both disdain the sort of philosophy that is practiced within the walls of the academy. The spirit, Savater suggests (15) and Santayana would agree, cannot fly free if chained to the ground by footnotes. Professionalism and sheer scholarship are to their eye incompatible with a truly philosophical mind. This does not mean, however, that they fail to recognize the specificity of philosophy. If anything, in "Borges, Philosophical Poet" Savater adheres to the view, put forward by Santayana in Three Philosophical Poets: Lucretius, Dante, and Goethe, that philosophy differs from literature in method as well as in scope. Nevertheless, poetic intuition and philosophical vision aspire to apprehend the same order in the world: philosophy stems from a comprehensive experience which lies also at the bottom of poetry in its peak. No wonder, then, that literature can convey theoretical insights or philosophers can occasionally resort to literary expression in order to capture that experience. This taste for literature as a proper companion to philosophy is characteristic of Santayana and Savater, and it is a pity that the latter does not pursue this particular topic any further. His brief comment on Borges is wellaimed and insightful, but the parallelisms between Borges and Santayana deserved a much more developed treatment. 
5 Another coincidence is a shared scepticism, not just in the confined epistemological sense of the term, but as a general attitude toward abstract ideals and comforting illusions. Savater bows to what Santayana himself described as his 'philosophical cruelty.' And he admires it all the more because in Santayana such attitude was not pathetic or resented, it did not invite resignation nor despair, but a tranquil acceptation, if at all. Savater quotes repeatedly Santayana saying that "we live dramatically in a world that is not dramatic"; he places his name in a list including Seneca, Spinoza, Kierkegaard, Nietzsche, and Cioran (15). All these are important influences in Savater's own philosophy, of course, but he acknowledges that he finds Santayana's ironic and non-emphatic tone especially congenial. Savater's intellectual mood is more playful than ironic, and his personality definitely more sanguine as compared to Santayana's cold affability, but he rightly detects the subtle humour that Santayana's polished prose often exudes.

6 Most pages of the book are devoted to evoke Santayana's oddity: the man who preferred to be a life-long student rather than a professor, the cosmopolitan that refused to settle down and make his home in any place, an outsider who never belonged nor cherished belongings. Savater praises Santayana for being a genuinely original person, not just an eccentric (117), and his independence fascinates him. But this fascination is punctuated with drops of impatience: "Maybe he lacks rapture, folly, passion [...]. He is always a bit too outside as to arouse whether adhesion or abhorrence: out of time, out of taste, out of fashion and tradition, out of orbit" (65). This was certainly the impression that Santayana made on those who met him. Savater says that he first knew about Santayana by reading Bertrand Russell's Portraits from Memory, and it is plain that Russell's lack of enthusiasm for Santayana left a permanent mark on Savater's opinion.

7 The philosophical topic on which Savater seems to be closer to Santayana is aesthetics. The most remarkable text of this anthology, to my view, is "Concept and Aesthetics in George Santayana" (41-51); originally published in Spanish in 1985, it was later translated into English and published in Overheard in Seville. Bulletin of the Santayana Society, 13 (1995). This is a brief but penetrating, cogent essay on Santayana's ideas concerning the relationship of aesthetics to ethics and on Santayana's rejection of aestheticism as being the mark of 'barbarism' in modern art. Arguing against the idealism of Benedetto Croce or Bernard Bosanquet, Santayana claimed that beauty is connected and eventually subordinated to the whole of human values, thus affirming a full-blooded naturalism in aesthetics. Savater finds an echo of these ideas in some criticisms that the anthropologist Claude Lévi-Strauss directed in Le regard éloigné (1983) against modern painting. Though Savater sees some partiality in their judgment, he recognizes the soundness and pertinence of the general position that both Santayana and Lévi-Strauss were trying to enforce. On this point, Santayana's naturalism and Savater's ethical perspective seem to find a common ground and eventually endorse the same position.

8 By contrast, Savater disregards Santayana's endeavour to produce a system of philosophy. He finds the project outdated even in its time $(66,129)$, which is a rather striking remark provided that Santayana was contemporary with Royce, Whitehead, Husserl, Dewey, and Russell, to mention only a few philosophers who also attempted to build a sort of philosophical system. When it comes to metaphysics Savater's interest loses heart and his perspicacity decays; the author reveals a poor understanding of 
Santayana's ontological distinctions (as, for instance, on page 128) or indulges in shallow, offhand comments (67-8).

9 Overall, this book bears testimony of a philosophical friendship. It is not scholarly or comprehensive, but it rewards the reader with a fresh presentation of Santayana as a remarkable philosopher and as a man of genius. It also benefits from Savater's readable, witty prose. The exhaustiveness of the compilation yields annoying, if inevitable repetitions. Anyway, a stronger editorial hand would have been appreciated in suppressing typos and superfluous editorial footnotes.

\section{AUTHORS}

\section{ÁNGEL M. FAERNA}

Universidad de Castilla-La Mancha

Angel.Faerna[at]uclm.es 